\title{
Postmodern/Post-mortem Human Body-Parts: Grotesque Subjects in The Melancholy of Anatomy
}

\author{
Jharna Choudhury \\ PhD Scholar, Tezpur University, Assam, India. ORCID ID: 0000-0002-0916-373. \\ Email: jharnachoudhury123@gmail.com
}

\begin{abstract}
This paper critiques the literary representation of the human body as a "clean" slate, an organically wholesome subject by delving into the postmodern body-writing of Shelley Jackson's short story collection The Melancholy of Anatomy (2002). Building upon the idea of "metabody" or grotesque body-part as subjects, the flesh-characters, namely Egg, Sperm, Foetus, Cancer, Nerve, Phlegm, Blood, Milk and Fat, breaks apart from their marginality, and evolves in a rhizomatic structure, pressing their possibilities of manifold existence in a fantastical world. Through the lens of body studies critics (Mikhail Bakhtin and Elisabeth Grosz) and recent postmodern scholarship, the paper studies the performance of flesh-characters, creating a post-mortem pathology in literature. Jackson's deviant approach re-maps the anatomy of the human body and engages in psychophysiological parodies, thereby disclosing social phobias pertaining to the repulsive sides of the human and feminine body. Metabodies are self-reflexive, postmodern grotesque, with micro-narratives; and their innovative representations give agency and consciousness to the usually discarded body-parts and fluids, thereby making the human body a non-normative and discursive text and context.
\end{abstract}

Keywords: Postmodern; Shelley Jackson, Grotesque, Metabody, Human Body

\section{Introduction}

Postmodern anxiety is intrinsically connected to post-mortem topography, the balance of whole and fragment. This paper aims to explore the neologism "metabody", as a self-reflexive body, something against the totalizing flesh-narrative which is considered incredulous in a postmodern text. While revisiting Robert Burton's medical treatise The Anatomy of Melancholy (1621), Shelley Jackson's short story collection The Melancholy of Anatomy (2002) presents the darker interiors of the body, characterizing human organs through caricature and grotesque subjectivity. Jackson's narrative framework augments the already extensive postmodern scholarship; her schizophrenia of flesh offers, what body-studies critic Elizabeth Grosz comments as, "point of twisting or selftransformation in which the inside flips over to become the outside, or the outside turns over on itself to become the inside" ( Grosz, 1994, p. 160).

Set against the hypothesis that human organs are postmodern subjects; this paper analyses the micro-narratives of the body-parts, against a dominating single-dimensional

This Open Access article is published under a Creative Commons Attribution Non-Commercial 4.0 International License (http://creativecommons.org/licenses/by-nc/4.0/), which permits non-commercial re-use, distribution, and reproduction in any medium, provided the original work is properly cited. For citation use the DOI. For commercial re-use, please contact editor@rupkatha.com. 
narrative that resembles "the obsolescence of the metanarrative apparatus of legitimation" (Lyotard et al., 1984, xxiv). The text changes the ontological status of human organs, not by translating the meaning of the interiors, but by challenging the idea of a wholesome body through hyperbolic subjectivity endowed on singular body-parts like egg, sperm, foetus, cancer, nerve, phlegm, hair, blood, milk and fat. These fragments have a physical and equally psychical existence, thereby commenting on the importance of bodily excess, which is otherwise considered of a lower order in the hierarchy of body-parts. Taking a biologistic view, the paper explores Grosz's question, "What happens to conceptual frameworks if the body stands in place of the mind or displaces it from its privileged position defining humanity against its various others?" (Grosz, 1994, p. 160).

There is a continuous post-mortem of body-parts in this collection, and they are given a chance to exist and disclose their identities and idiosyncrasies, for themselves, participating in a postmodern consciousness. The essay, "What Is Postmortem Pathology: Why and How We Do It", explains that "postmortem means 'after death'" (McManus et al., 2014, p. 3423), while autopsy derives from the "Greek autos (= self) and op- (=see), the word autopsy literally means to 'see for oneself'" (McManus et al., 2014, p. 3424). In Jackson's stories, the bodyparts are in a condition that deconstructs or annihilates the normal idea of a wholesome body, foregrounding body orifices and fluids which are now self-reflexive in the text. The new bodies alter the normal living condition, engages in a carnival with "abuses, uncrownings, teasing, and impertinent gestures" " (Bakhtin \& Iswolsky, 1984, p 341). They occupy a liminal position, examined in two different ways, " 'necropsy' may be considered the procedure to examine the dead (nekros = dead or corpse), similar to how a 'biopsy' is the procedure used for examinations in the living (bios = life)" (McManus et al., 2014, p. 3424). The body-parts straddle between procreation and death, surreal and real worlds; speaking for varied body excess, which has been misrepresented, disgusted and erased in the literary representation of human bodies.

\section{Postmodern Grotesque Bodies}

Considering that, "body is commonly considered a signifying machine, a vehicle of expression, a mode of rendering public and communicable what is essentially private" (Grosz, 1994, p. 9), contemporary artists like Francesco Albano (his artworks are Whirlpool, Ballerina ), Jonathan Payne (who sculpted the Fleshlette Family), etc, have taken the idea of the private body to its extreme, by reproducing grotesque interiors, turning the body "'inside out"' (Bakhtin \& Iswolsky, 1984, p. 11). There are three prominent elements of postmodernism, which reveals themselves in the grotesque nature of the body-parts in The Melancholy of Anatomy. First, using Deleuze and Guattari's rhizome metaphor, recent postmodern scholars saw how the "rhizome is one structure which does not try to impose an order, but in which connections are ever-changing (as all of the nodes are also constantly in flux)" (Stephan, 2019, p. 62). This is applicable in analysing the hyperreal condition inside Jackson's text, where "depiction of a more-than-rea/by virtue of their aim to pass not for the thing itself, but for another form of representation" (Lucy et al., 2016, p.90). The body-parts are interconnected, yet singular "newly conceived body" (Bakhtin \& Iswolsky, 1984, p. 318), in the Bakhtinian sense of the term; they are cosmic, comic, carnivalesque and universal. In Shelley Jackson's stories, Imogen's Egg is conceived on her face (like a zit) and eventually 
transforms into a grotesque creature which eats, swallows and expels; Sperms run a cabaret; the Foetus is a shapeless voyeuristic citizen with chivalry; Cancer lives in a house like a pet animal which eventually grows bigger; Nerves in George's town are utilized in making furniture, dolls, hats and sculptures; phlegm production is a reputable business and a skill that is advertised to be mastered; menstrual blood fills the sewers of a London town and a woman named "Blood Lark" make a living out of cleaning it; while milk replaces water; fat is edible and feasted upon. If rhizomes are "root structures that do not have a center", acting on a "plane of immanence" (or mesh of relations that has no foundation, ground or outside)" (Lucy et al., 2016, p. 34), then each body element in this text behaves in a rhizomatic structure, inside a fantastical world.

The second element of postmodern grotesque is the dialogue of the fragmented bodies against the totalitarian perspective of a unitary body. Bakhtin's The Dialogic Imagination (1981) explains how postmodernism is possible through a parody of the direct word (Emerson et al., 1981, p. 60). His views are enhanced by recent critics, who saw how dialogism aimed "to open language to social determination, newness, change and struggle, including the dialectics of difference between official and popular socio-cultural forces: authority and carnival; literature and popular culture; the discourse of the intelligentsia and that of the denizens of the "carnival square" "'Lucy et al., 2016, p. 40). It is here, we see that the marginal elements of the human body, which are essentially disregarded as gross are given a voice, a personality, to challenge the binary of "good" body-parts and "bad" body-parts.

Jackson's elaborate world of sperm is a dialogue of possibilities, where "trained sperm are squeezed into specially made costumes, and they dances and flop about" (Jackson, 2002, p. 38); also sperms can be hunted down as a sport, they are a recipe, they can be trapped in nets and kept in small bowls as pet fishes, used as bonsai. While Foetus, which are "made of something like our flesh, but not the same, it is a sort of über flesh, rife with potentialities" (Jackson, 2002, p. 51); they walk about the town, susceptible creatures with oversized heads, helping pregnant women cross roads, tending gardens, hiding in boxes and hollowed trees, initiating a new-normal, when the narrator speculates about its dubious origin, saying, "Was the foetus a foetus?" (Jackson, 2002, p. 48). The dialogic nature is also present in the story "Milk" which alters acceptable vocabularies by replacing water with milk and henceforth cloud becomes a milk-secreting organ and rain equates lactation. Apart from humans or walking clouds, there are other types of corporeal clouds with malfunctions like the sick cloud (quivering and tired), cystic cloud (forcibly deprived of milk), and hysterical cloud (show signs of milk release but is dry).

The third element of the postmodern grotesque is the use of open-ended bodies. Bakhtin calls this situation "temporary suspension, both ideal and real, of hierarchical rank (Bakhtin \& Iswolsky, 1984, p. 10), or unwriting the reduced rank of a closed-body (body with its limits set). Such micro-narratives of bodies allow the exaggerated, unfinished and marginal body-parts to exist. Jackson's flesh-character, the Cancer, posses an animal presence, growing in the middle of a living room, like a Rumpelslitskin (an imp in German folktales), a hairy nymph, a place rather than a living thing, also a rooting hydrotropic plant. Its corporeality is as open as the foetus, which is "unfinished-perpetually" (Jackson, 2002, p. 51). Adhering to Bakhtinian grotesque of "yet unfinished metamorphosis" (Bakhtin \& Iswolsky, 1984, p. 24), the story "Nerve" projects polysemic human nerves, used as aphrodisiacs, amulets, grown into fields, fibres, play dolls, challenging its 
singular bodily existence. There is a lurking uncertainty about the beginning and end of the bodypart or its corporeal matter; which is both postmodern and grotesque in nature.

\section{Self-Referential Body-Parts}

Literary postmodernism owes a lot to "the writings of Mikhail Bakhtin - particularly the concepts of dialogism, heteroglossia, polyphony, the chronotope and the carnivalesque - and later theorists such as Roland Barthes and Jacques Derrida, the texts [sic] of the postmodernists were selfreflexive, playful and exceedingly aware of the medium of language" (Sim, 2011, p. 169). Shelley's Jackson's The Melancholy of Anatomy projects self-referential body-parts, who philosophize their postmodern existence. They are caught in micro-narratives, abound in characteristics like "temporal disorder; the erosion of the sense of time; a pervasive and pointless use of pastiche; a foregrounding of words as fragmenting material signs; the loose association of ideas; paranoia; and vicious circles, or a loss of distinction between logically separate levels of discourse (Sim, 2011, p. 171). The stories are intertextual; a conglomeration of ethnographic legends, social registers, textbook styles, newspaper clips, etc. They deliver the aesthetics of the supposed "ugly" and grotesque.

The metabodies in the text are self-referential in the sense that they reflect upon their situation in the narrative. Firstly, we are inside a text which is self-aware of its purpose; a text which is autotelic in essence, and hails the importance of body excess and its representation because what is a "perfect" body is a dubious question. To say,

"Existence is approximation; we are because of a kind of blurring of the material world. All attempts at perfection are destructive, therefore" (Jackson, 2002, p. 74).

One such approximate is possible by the postmodern technique of "blurring the boundaries between use and abuse of the body and accustoming us gradually to the idea that the human body is not a unitary whole, but a set of separable parts, therefore, transplantable from time to time" (Russo, 2020, p. 81). Jackons' imperfectly extraordinary pink/syrupy Egg-character initiates a discourse of folklore of eggs where eggs are capable of devouring humans, they are immortality pills, fashioned out of an unknown substance, and if properly taken care of, they would hatch saviours. To say, it is aware of its own deviance; that it "is manifold [...] It's the all-purpose object of desire, the placeholder for every operation [...] Egg, therefore I am" (Jackson, 2002, p. 22). For Solander, the Egg reflects on the "simultaneous fear and desire of being devoured by the maternal body points forward to dilation, a concept especially related to fat or pregnant females with gaping, greedy orifices" (Jackson, 2002, p. 123). The Egg is given contradictory meanings; seen as a bride, a femme fatale, an angel from the sky; and all attempts of Imogen (Egg's host) to be devoured by the giant egg, her leaps and forceful entry inside the egg-matter fails because the Egg spits her out and rejects her; thereby asserting its agency.

Again, the Cancer character is also multiple in composition. The narrator suspects that the Cancer is secreted by her nostril, and its corporeality is explained as "a starfish with split ends, an animal snowflake" (Jackson, 2002, p. 57) and "a buoyant object one tries to force under water" (Jackson, 2002, p. 59). The Cancer turned out to be a grotesque "freak" inside the house, who would reflect on the importance of its host and build a tunnel to reach the narrator, wherever she goes. In the story "Nerve", George works in a "nerve factory" which manufactures nerve bundles, 
to be designed mostly into hats. This story is self-reflective; and it comments on the postmodern human condition, saying, "We drop dead cells by the billions and go racing on in a flurry of dandruff [...] there is no economy to our carrying on, nor should there be" (Jackson, 2002, p.80). The story "Milk" on the other hand situates in a surreal world where milk is the surrogate of water, the narrator here reflects upon the metaphorical frenzy of anthropomorphizing our environment; in this case, the story "anthropomorphize these clouds" (Jackson, 2002, p. 161).

The story "Blood" parodies Robert Burton's belief that menstrual blood corrupts the female mind by inviting melancholy. As critic Solander discusses, by "placing "Blood" under the "Sanguine" heading and characterising the blood larks as bold, hearty and amorous to match the sanguine temperament, Jackson subtly overthrows the sexed hierarchy of humouralism" (Solander, 2013, p. 62). Jackson's samples of postmodern bodies challenge prevalent systems of viewing human bodies as complacent. Through what is called "tactile (meta)textuality" (Solander, 2013, p. 31), she creates metabodies to speak what was previously unspeakable in language; the story of "dirty" body-parts, now turned into active subjects. In "Phlegm", the characters can express their minds through a release of phlegm from the vent of their throats. This certainly embodies a carnivalesque world where, as Grosz questioned, "body stands in place of the mind" (Grosz, 1994, p. 160).

The story "Fat" on the other hand, is about a dilated world where fat-matter questions its performative shock value. It discusses a wedding scene where the bride and the groom look like fat-blobs, behemoths, whose naked bodies are encased in fats; and they are carried in a trolley along the aisle, where people would scoop fat from their bodies, as a ritualistic transaction. Often denounced as a grotesque category, "fatness" here self-reflects through a "fat" language; where adjectives are meticulously implying social fatphobia. The postmodern way of writing through the body is evidentiary in the way the couple's relationship is narrated; their wedding kiss being the "first bite of spousal fat"; also, in their row the husband "whispered foul words to me: buttery, oleaginous, pinguid, adipose [sic]" (Jackson, 2002, p. 169). This self-reflexive fat-body makes the reader aware of the process of storywriting/body-writing: "I am writing to tell you I'm still eating" (Jackson, 2002, p. 169), making a case of its self-choice. Jackson's corporeal experimentations draw out a self-referential language. In this text, each body-part post-mortem themselves and reflect upon their own "aesthetics of distaste" (Solander, 2013, p. 110), their scatological humour. It reconfigures bodily percepts which recuse the objectified body-parts from the surgeon's table and enables them to perform as subjects with a voice.

\section{Conclusion}

The postmodern and post-mortem grotesque metabodies in Shelly Jackson's text The Melancholy of Anatomy overturns the power of an organic and wholesome body by highlighting the assemblage of body fluids and body-parts. To quote, "Jackson does not merely draw upon bad taste for shock value but performs an earnest literary interrogation into the possible aesthetic values of substances and phenomena deemed distasteful" (Solander, 2013, p. 113). This direction adds to the possibilities of using postmodern techniques in a text to enhance modes of bodywritings, writing about the body, through the human body itself. Jackson's stories create: 
"BwO for queers to come by making new connections, new intensities, new organs. Despite what the name suggests, the BwO is to be understood as organs without a body rather than a body without organs" (Solander, 2013, p. 37).

The organs are free to think, enact and perform inside a text. In the line of écriture feminine writing, Jackson's body-writing too anatomizes language itself. It introduces corporeal vocabularies. The metabodies that represent the usually discarded body fluids and body-parts shatter the dominating language of the one-dimensional body and challenges myths of perfection.

This paper observes that what Shelley Jackson offers is a post-mortem human body model; pushing its limits of existence and signification. Through necropsy and biopsy-like processes, she opens the body-parts from hierarchical systems and enables them to interact with the outside world. Metabodies, like metafiction and metalanguage, self-reflects upon the aspect of "becoming" corporeal, or becoming visible and acceptable. The grotesque and marginal speaks, like the subaltern subjects. Through defamiliarization, the grand narrative of one human-body is dismantled; instead, micro-identities are created; and these micro-tales of the characters: Egg, Sperm, Foetus, Cancer, Nerve, Phlegm, Blood, Milk and Fat, resist closure. Their multiple endings

present the readers with the paranoia of flesh; making the human-body a discursive text and context.

\section{References}

Bakhtin, M. M. (1981). The Dialogic Imagination: Four Essays. (C. Emerson \& M. Holquist, Trans.). University of Texas Press.

Bakhtin, M. M. (1984). Rabelais and His World. (Iswolsky Hélène, Trans.). Indiana University Press.

Flomenbaum, M. (2014). What Is Postmortem Pathology: Why and How We Do It. In L. M. McManus \& R. N. Mitchell (Eds.), Pathobiology of Human Disease A Dynamic Encyclopedia of Disease Mechanisms (pp. 3423-3436). essay, Elsevier Science \& Technology. https://www.sciencedirect.com/science/article/pii/B9780123864567067010?via\%3Dihub.

Grosz, E. A. (1994). Volatile Bodies: Toward a Corporeal Feminism. Indiana Univ. Press.

Jackson, S. (2002). The Melancholy of Anatomy: Stories. Anchor Books.

Lucy, N., Thwaites, T., Hartley, J., Colebrook, C., Tofts, D., Briggs, R., \& Wark, M. K. (2016). A Dictionary of Postmodernism. (J. Hartley, Ed.). Wiley-Blackwell.

Lyotard Jean-François. (1984). The Postmodern Condition: A Report on Knowledge. (G. Bennington \& B. Massumi, Trans.). Univ. of Minnesota Press.

Russo, M. T. (2020). The human body as a problem in post-modern culture. Church, Communication and Culture, 5(1), 74-91. https://doi.org/10.1080/23753234.2020.1713010

Sim, S. (Ed.). (2011). The Routledge Companion to Postmodernism (3rd ed.). Routledge.

Solander, T. (2013). "Creating the senses" sensation in the work of Shelley Jackson (thesis). "Creating the Senses" Sensation in the Work of Shelley Jackson. Umeå universitet. Retrieved from http://umu.diva-portal.org/smash/record.jsf?pid=diva2\%3A605465\&dswid=2345 
7 Postmodern/Post-mortem Human Body-Parts: Grotesque Subjects in The Melancholy of Anatomy

Stephan, M. (2019). Defining Literary Postmodernism for the Twenty-First Century. Palgrave Macmillan.

Jharna Choudhury, is a PhD research student from the Department of English, Tezpur University, Assam, India. She is working on her dissertation on representations of grotesque bodies in contemporary fiction. 